\title{
Tetrahedral cage complex with planar vertices: selective synthesis of Pt4L6 cage complexes involving hydrogen bonds driven by halide binding
}

Masaki Ito, Masato Iseki, Masumi Itazakia and Hiroshi Nakazawa

\begin{tabular}{|c|l|}
\hline Citation & Chemical Communications, 52(45): 7205-7208 \\
\hline Issue Date & $2016-6-7$ \\
\hline Type & Journal Article \\
\hline Textversion & author \\
\hline Rights & $\begin{array}{l}\text { This is the accepted manuscript version. } \\
\text { The article has been published in final form at http://doi.org/10.1039/C6CC01448H. } \\
\text { Please cite only the published version. }\end{array}$ \\
\hline DOI & $10.1039 / \mathrm{C} 6 \mathrm{CC} 01448 \mathrm{H}$ \\
\hline
\end{tabular}

Self-Archiving by Author(s) Placed on: Osaka City University Repository 


\section{ChemComm}

\section{COMMUNICATION}

\section{Tetrahedral Cage Complex with Planar Vertices: Selective Synthesis of $\mathrm{Pt}_{4} \mathrm{~L}_{6}$ Cage Complexes Involving Hydrogen Bonds Driven by Halide Binding ${ }^{\dagger}$}

Received 00th January 2016 Accepted 00th January 2016

DOI: $10.1039 / x 0 x \times 00000 x$
Masaki Ito, Masato Iseki, Masumi Itazaki, Hiroshi Nakazawa*

www.rsc.org/chemcomm

The reaction of $\mathrm{Fe}\left(\eta-\mathrm{C}_{5} \mathrm{H}_{4} \mathrm{NHC}(\mathrm{O}) \mathrm{PPh}_{2}\right)_{2}$ (L) with $\mathrm{PtX}_{2}\left(\mathrm{PPh}_{3}\right)_{2}$ selectively formed cage-shaped complexes formulated as $\left[(\mathrm{PtX})_{4}(\mathrm{~L})_{6}\right] \mathrm{X}_{4} \cdot \mathrm{CHCl}_{3}(\mathrm{X}=\mathrm{Cl}, \mathrm{Br})$, in which the four square-planar $\mathrm{Pt}$ fragments were situated at each vertex and the six Ls were located in each side of a tetrahedral framework and hydrogen bonds existed between the $\mathrm{NH}$ groups in Ls and $\mathrm{X}^{-}$ions inside the cage.

In the last few decades, the chemistry of metal-organic cage complexes has developed rapidly because of their fascinating structures and potential applications, ${ }^{1}$ and controllable synthesis of metal-organic cage complexes is still a great challenge. Many systems involve using rigid frameworks to control the geometry and symmetry of the final architecture (e.g., 4,4'-bipyridine, ${ }^{2}$

1,3,5-tris ( 4

(diphenylphosphino)ethynyl)phenyl)benzene ${ }^{3}$ ). Recently, some discrete assemblies were synthesized by introducing organic ligands with flexible arms such as methylene, but these were restricted to ligands with three or more coordination atoms. ${ }^{4} \mathrm{~A}$ template-directed strategy is also a powerful method for selective construction of molecular assemblies. ${ }^{4 g-i,} 4 k-n, 5$ However, the template molecule should be removed in order to use the internal cavity, since it occupies the internal space in many cases.

Herein, we report an unprecedented selective synthesis of $\mathrm{M}_{4} \mathrm{~L}_{6}$ cage complexes using a flexible ligand with two coordination parts and without addition of a particular template molecule. The reaction of new 1,1'-ferrocene derivative $\mathrm{Fe}\left(\eta-\mathrm{C}_{5} \mathrm{H}_{4} \mathrm{NHC}(\mathrm{O}) \mathrm{PPh}_{2}\right)_{2}$ (L) with $\mathrm{PtX}_{2}\left(\mathrm{PPh}_{3}\right)_{2}$ gave $\left[(\mathrm{PtX})_{4}(\mathrm{~L})_{6}\right] \mathrm{X}_{4}$, adopting a tetrahedral framework. In the cavity, hydrogen bonds formed between the $\mathrm{NH}$ groups of phosphinecarboxamidyl moieties and halide ions derived from $\mathrm{PtX}_{2}\left(\mathrm{PPh}_{3}\right)_{2}$ immediately below each vertex of the cage.

First, 1,1'-bis(phosphinecarboxamidyl)ferrocene, L, was

Department of Chemistry, Graduate School of Science Osaka City University Sumiyoshi-ku, Osaka 558-8585, Japan

E-mail:nakazawa@sci.osaka-cu.ac.jp

† Electronic Supplementary Information (ESI) available: For ESI and crystallographic data in CIF or other electronic format see DOI: 10.1039/x0xx00000x prepared via the reaction of $\mathrm{Fe}\left(\eta-\mathrm{C}_{5} \mathrm{H}_{4} \mathrm{NCO}\right)_{2}$ with diphenylphosphine for $1 \mathrm{~h}$ at $100{ }^{\circ} \mathrm{C}$ in toluene (Scheme 1). Ligand $L$ was characterized by ${ }^{1} \mathrm{H},{ }^{13} \mathrm{C}\left\{{ }^{1} \mathrm{H}\right\}$, and ${ }^{31} \mathrm{P}\left\{{ }^{1} \mathrm{H}\right\} N M R$ spectroscopy, and elemental analysis. In the ${ }^{31} \mathrm{P}\left\{{ }^{1} \mathrm{H}\right\} \mathrm{NMR}$ spectrum, $\mathbf{L}$ showed a singlet at $\delta=-2.06 \mathrm{ppm}$ in the range expected for a phosphinecarboxamide. ${ }^{6}$ The molecular structure was confirmed by single-crystal X-ray structure analysis (see ESI, Fig. S22). No intramolecular hydrogen bond was observed. The $\mathrm{P}-\mathrm{C}$ bond length was $1.886(2) \AA$, which was slightly longer than the sum of the single-bond covalent radii for the elements $(1.80-1.86 \AA)^{7} .^{7}$ The $\mathrm{C}-\mathrm{O}$ and $\mathrm{C}-\mathrm{N}$ bond distances were consistent with those of other carboxamides in the literature. ${ }^{8}$ These results indicate significant delocalization of $\pi$-electron density between the carbonyl and amide groups and no significant $\pi$-interaction between the phosphine lone pair and the carbonyl carbon.
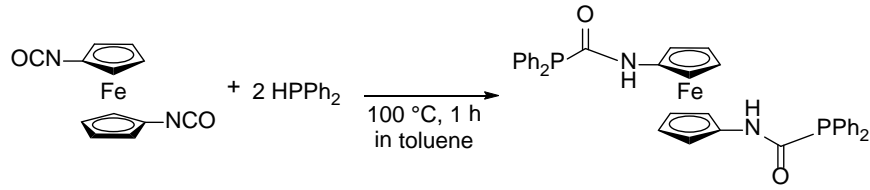

L: $63 \%$

Scheme 1 Synthesis of ligand L.

Next, we attempted a reaction of $\mathbf{L}$ with zero-valent platinum complex $\mathrm{Pt}\left(\mathrm{PPh}_{3}\right)_{4}$ because Goicoechea's group has reported the first transition metal complexes of phosphinecarboxamide $\left(\mathrm{H}_{2} \mathrm{NC}(\mathrm{O}) \mathrm{PH}_{2}\right)$ in which a phosphorus atom coordinates to the transition metal. ${ }^{9}$ The reaction shown in Scheme 2 afforded poorly soluble complex 1 identified by EA and X-ray structure analyses (see ESI, Fig. S23). Complex $\mathbf{1}$ has a four-coordinate tetrahedral geometry around the platinum center and $\mathbf{L}$ behaves as a bidentate ligand.

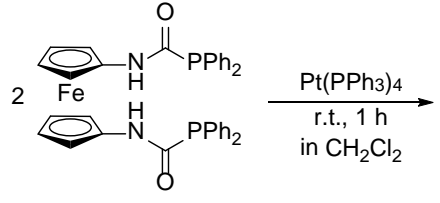

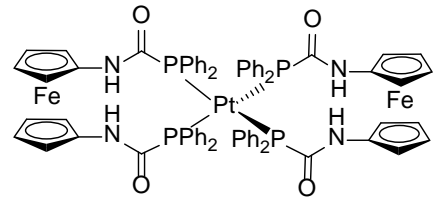

1: $68 \%$
Scheme 2 Reaction of $\mathbf{L}$ with $\mathrm{Pt}\left(\mathrm{PPh}_{3}\right)_{4}$ 
In contrast, the reaction of $\mathbf{L}$ with divalent platinum complex $\mathrm{PtX}_{2}\left(\mathrm{PPh}_{3}\right)_{2}$ in chloroform led to unexpected results (Scheme 3 ). The suspension was vigorously stirred at room temperature to provide a red solution within a few minutes. Red crystals were obtained upon diffusion of $n$-hexane vapor into the chloroform solution. The crystal structures revealed that the $M_{4} L_{6}$ cage complexes were formed and one solvent molecule and four $\mathrm{X}^{-}$ ions from Pt centers were encapsulated $\left(\left[\mathrm{CHCl}_{3} \subset \mathbf{2 a}\right]\right.$ : Fig. 1, $\left[\mathrm{CHCl}_{3} \subset \mathbf{2 b}\right.$ ]: Fig. 2). The four square-planar Pt(II) centers were bridged by six Ls. The structure displays $S_{4}$ symmetry. This is the first report of an $\mathrm{M}_{4} \mathrm{~L}_{6}$ platinum-organic cage complex. ${ }^{10}$

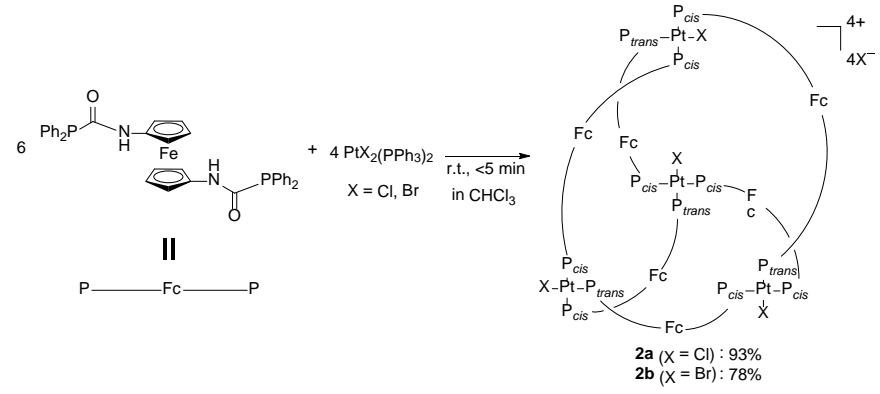

Scheme 3 Reaction of $\mathbf{L}$ with $\mathrm{PtX}_{2}\left(\mathrm{PPh}_{3}\right)_{2}$.

The $\mathrm{N}-\mathrm{Cl}$ and $\mathrm{N}-\mathrm{Br}$ distances were 3.120(10)-3.339(9) and 3.238(10)-3.402(9) $\AA$, respectively. These results indicate the existence of a hydrogen bond, which is shown as $(\mathrm{N}-\mathrm{H})_{3} \cdots \mathrm{X}^{-}$. Molina's group has reported a ferrocene-based urea in which the $\mathrm{NH}$ group acted as a strong hydrogen-bonding site for $\mathrm{F}^{-}$or $\mathrm{H}_{2} \mathrm{PO}_{4}{ }^{-11,12}$ Hydrogen bonding is a well-precedented strategy for multicomponent self-assembly. ${ }^{4 k}, 41,5 f$ In the crystal structure of $\left[\mathrm{CHCl}_{3} \subset 2 \mathrm{a}\right]$, three chloroform chlorine atoms are facing $\mathrm{Cl}^{-}$ions in the cage, and the $\mathrm{Cl} \cdots \mathrm{Cl}$ interaction (halogen bonding $)^{13}$ is formed (Pt-Cl$\cdots \mathrm{Cl}-\mathrm{C}$ distance is 3.110(6)3.308(6); these distances are shorter than that reported previously $\left.{ }^{13 a, 13 b}\right)$. In contrast, the chloroform is arranged to be separated from $\mathrm{Br}^{-}$ions in the structure of $\left[\mathrm{CHCl}_{3} \subset \mathbf{2 b}\right]$.

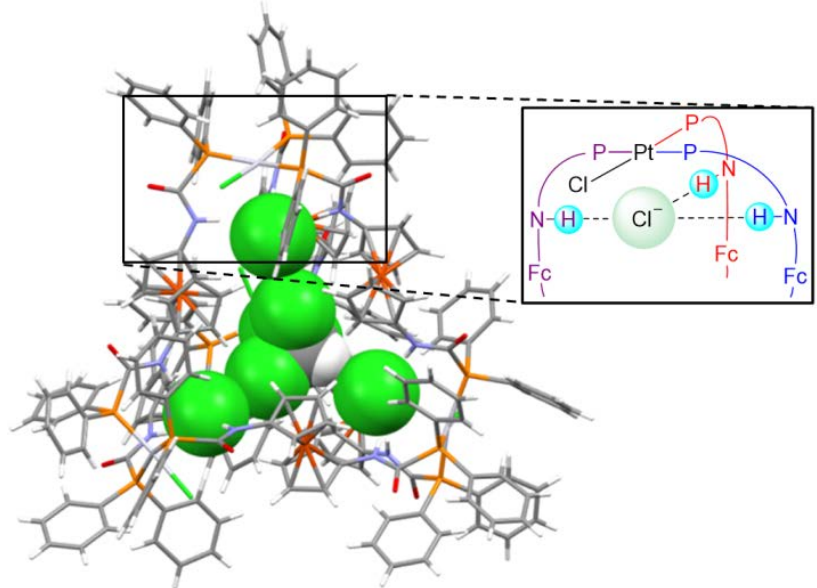

Fig. 1 Crystal structure of $\left[\mathrm{CHCl}_{3} \subset 2 \mathrm{a}\right]$. All solvent molecules except one in the cavity are omitted for clarity. Selected bond lengths $(\AA)$ and angles $\left({ }^{\circ}\right)$ : $\mathrm{Pt}-\mathrm{P}_{\text {trans }}=$ 2.256(3)-2.270(2), $\mathrm{Pt}-\mathrm{P}_{\text {cis }}=2.323(2)-2.344(3), \mathrm{Pt}-\mathrm{Cl}=2.350(3)-2.364(3), \mathrm{P}-\mathrm{C}(\mathrm{O})$

$=1.866(12)-1.935(11), \quad \mathrm{N}-\mathrm{C}(\mathrm{O})=1.316(17)-1.360(12), \mathrm{N}-\mathrm{Cl}=3.120(10)-$ 3.339(9); $\mathrm{P}_{\text {cis }}-\mathrm{Pt}-\mathrm{P}_{\text {trans }}=93.74(9)-98.02(10), \mathrm{P}_{\text {cis }}-\mathrm{Pt}-\mathrm{Cl}=80.09(9)-88.63(10)$.

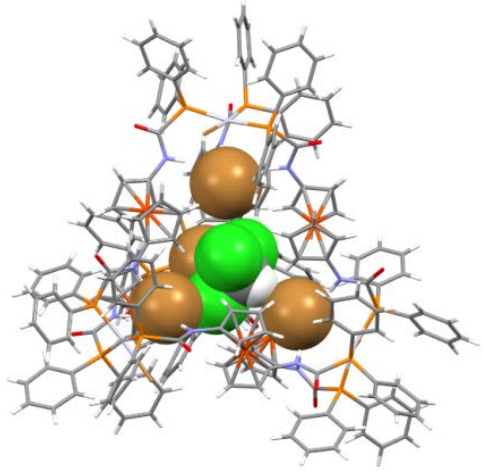

Fig. 2 Crystal structure of $\left[\mathrm{CHCl}_{3} \subset \mathbf{2 b}\right.$ ]. All solvent molecules except one in the cavity are omitted for clarity. Selected bond lengths $(\AA)$ and angles $\left({ }^{\circ}\right)$ : Pt $-P_{\text {trans }}=$ $2.267(3)-2.286(2), \mathrm{Pt}-\mathrm{P}_{\text {cis }}=2.327(3)-2.366(3), \mathrm{Pt}-\mathrm{Br}=2.4804(12)-2.5030(10, \mathrm{P}-$ $\mathrm{C}(\mathrm{O})=1.862(17)-1.921(9), \mathrm{N}-\mathrm{C}(\mathrm{O})=1.310(13)-1.351(13), \mathrm{N}-\mathrm{Br}=3.238(10)-$ 3.402(9); $\mathrm{P}_{\text {cis }}-\mathrm{Pt}-\mathrm{P}_{\text {trans }}=93.50(8)-96.47(9), \mathrm{P}_{\text {cis }}-\mathrm{Pt}-\mathrm{Br}=80.49(6)-89.25(7)$.

Leaving crystals of $\left[\mathrm{CHCl}_{3} \subset \mathbf{2 a}\right]$ and $\left[\mathrm{CHCl}_{3} \subset \mathbf{2 b}\right]$ under reduced pressure gave orange powders of $\mathbf{2 a}$ and $\mathbf{2} \mathbf{b}$, respectively, containing no guest molecule $\left(\mathrm{CHCl}_{3}\right)$. Complicated ${ }^{31} \mathrm{P}\left\{{ }^{1} \mathrm{H}\right\}$ NMR spectra of $\mathbf{2} \mathbf{a}$ and $\mathbf{2} \mathbf{b}$ were observed in solution at room temperature (Fig. 3a and ESI). Each signal was accompanied by broad ${ }^{195} \mathrm{Pt}$ satellite signals. The gNMR simulations of ${ }^{31} \mathrm{P}\left\{{ }^{1} \mathrm{H}\right\}$ NMR spectra were in excellent agreement with the observed spectra (Fig. $3 \mathrm{~b}$ and ESI). The corresponding gNMR simulated spectra have been fitted to $A B X$ spin systems where $A, B={ }^{31} P_{\text {cis } 1, \text { cis } 2}$ and $X={ }^{31} P_{\text {trans }}$. These results indicate that there are three chemically inequivalent phosphorus atoms in our cage molecules. In the ${ }^{1} \mathrm{H} N M R$ spectra of $\mathbf{2 a}$ and $\mathbf{2 b}$ in Fig. $3 \mathrm{c}$ and $\mathrm{ESI}$, the twelve peaks for $\mathrm{Cp}$ rings are sharp, indicating the cage structure rather than a non-discrete aggregate. The obvious down-field shift assigned to $\mathrm{NH}$ protons in the ${ }^{1} \mathrm{H}$ NMR spectrum suggests the presence of strong hydrogen bonding between the $\mathrm{NH}$ groups and $\mathrm{Cl}^{-}{ }^{-14}$ $\mathrm{Cl}^{-} \mathrm{s}$ would be immobilized in the cage. The NMR spectra revealed that the $\mathrm{X}$-ray structure was maintained in solution. The fact that $\mathrm{M}_{4} \mathrm{~L}_{6}$-type compounds $\mathbf{2} \mathbf{a}$ and $\mathbf{2} \mathbf{b}$ exist in solution was also supported by high-resolution electrospray mass spectrometry (ESI-MS) (see ESI, Figs. S10 and S17). The distinct peaks observed correspond to $[\mathbf{2} \mathbf{a}]^{2+}$ and $[\mathbf{2} \mathbf{b}]^{2+}$, and matched the simulated isotopic patterns well.

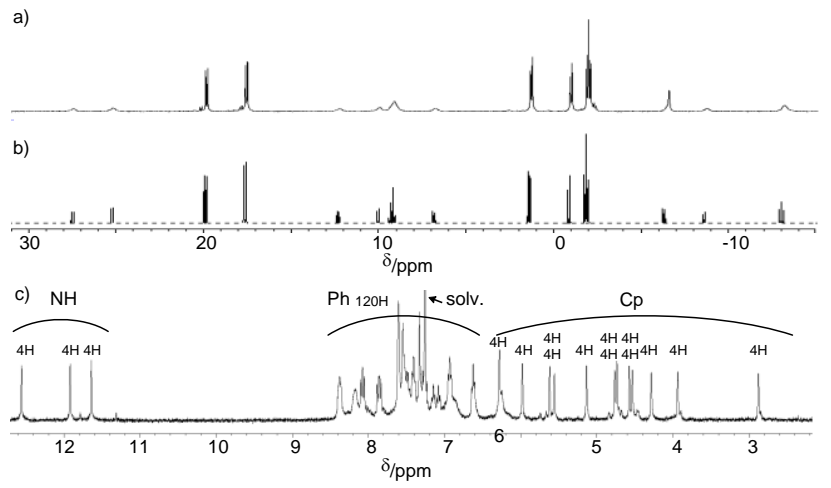

Fig. 3 (a) ${ }^{31} \mathrm{P}\left\{{ }^{1} \mathrm{H}\right\} \mathrm{NMR}\left(\mathrm{CDCl}_{3}, \mathrm{rt}, 161.7 \mathrm{MHz}\right)$ and (b) gNMR simulated spectra of 2a. (c) ${ }^{1} \mathrm{H}$ NMR spectrum $\left(\mathrm{CDCl}_{3}, 40^{\circ} \mathrm{C}, 400 \mathrm{MHz}\right)$ of $2 \mathrm{a}$. 
In metal-organic cage complexes ${ }^{1-5}$ and metal-organic frameworks ${ }^{15}$ reported thus far, the vertex or intersection component in molecular assemblies is a metal atom that roughly regulates the angle (Fig. 4 , left). The construction of an $\mathrm{M}_{4} \mathrm{~L}_{6}$ tetrahedral cage containing a square-planar metal center as the vertex component is far from easy because each vertex angle of a tetrahedron is $109.5^{\circ}$. Therefore, square-planar complexes have not been used at the vertex positions when constructing tetrahedral cage complexes. Complexes $\left[\mathrm{CHCl}_{3} \subset \mathbf{2 a}\right.$ ] and $\left[\mathrm{CHCl}_{3} \subset \mathbf{2 b}\right.$ ] reported in this paper are quite unique because they are tetrahedral cage complexes and four square-planar Pt complexes are located at the vertex positions (Fig. 4, right). Moreover, each Pt plane is perpendicular to the axis passing through the center of the cage and the vertex, showing that the $\mathrm{L}-\mathrm{Pt}-\mathrm{L}$ angle (ca. $90^{\circ}$ ) is not involved in the vertex angle of the cage structure. Another unique characteristic of our system is that a halide ion derived from the starting Pt complex is situated immediately below the Pt plane (in other words, just inside the cage structure) and forms hydrogen bonds with three $\mathrm{NH}$ groups in the three ligands of the Pt complex. These $(\mathrm{NH})_{3} \cdots X^{-}$hydrogen bonds keep the Pt complex at the vertex position, namely halide ions bind the ligands (halide binding), and eventually construct the tetrahedral cage complex. One halide out of two in the starting sequar planar $\mathrm{PtCl}_{2}\left(\mathrm{PPh}_{3}\right)_{2}$ moves, during the reaction, to the position below a Pt coordination plane (inside the cage), but still keeps a space available for a guest molecule $\left(\mathrm{CHCl}_{3}\right.$ in our case).
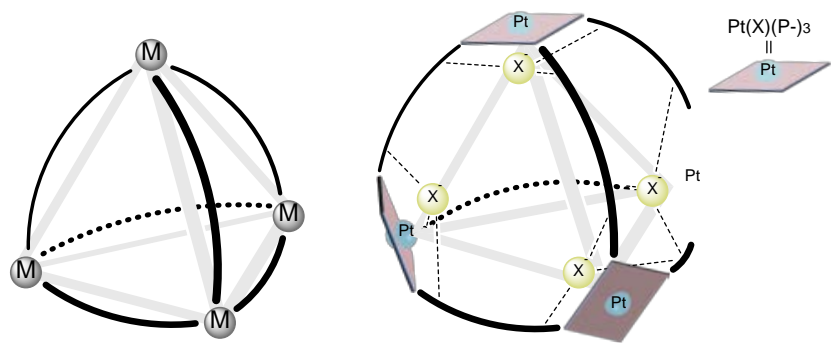

Fig. 4 Difference in the vertex for $M_{4} L_{6}$ tetrahedral cage complexes.

On the basis of the crystal structure of $\left[\mathrm{CHCl}_{3} \subset 2 \mathrm{a}\right]$, the Pt fragment shown in the inset in Fig. 1 is considered as a basic unit; 2a consists of four of the basic units. The phosphinecarboxamide $\mathrm{PhNHC}(\mathrm{O}) \mathrm{PPh}_{2}$ is a simplified version of $\mathbf{L}$, where the ferrocenyl group is replaced by a phenyl group. The reaction of $\mathrm{PhNHC}(\mathrm{O}) \mathrm{PPh}_{2}$ in place of $\mathbf{L}$ with $\mathrm{PtCl}_{2}\left(\mathrm{PPh}_{3}\right)_{2}$ was expected to afford a Pt complex similar to that shown in the inset in Fig. 1 . The reaction took place immediately and gave 3 in excellent yield (Scheme 4). The X-ray structure (Fig. 5) revealed that $\mathbf{3}$ corresponded to the $\mathrm{Pt}$ complex at the vertex position of $\left[\mathrm{CHCl}_{3} \subset \mathbf{2 a}\right]$. Therefore, the formation of $\mathbf{3}$ seems to be a driving force of our unique cage molecule.
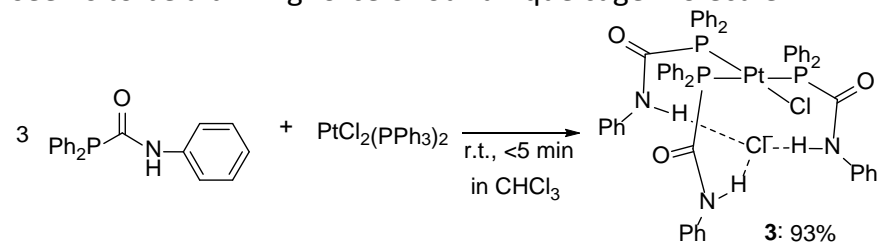

Scheme 4 Reaction of $\mathrm{PhNHC}(\mathrm{O}) \mathrm{PPh}_{2}$ with $\mathrm{PtCl}_{2}\left(\mathrm{PPh}_{3}\right)_{2}$.

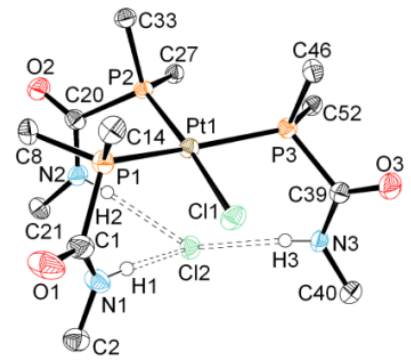

Fig. 5 ORTEP drawing of $\mathbf{3}$ (thermal ellipsoids at $50 \%$ probability). All hydrogen atoms, solvent molecules, and $\mathrm{Ph}$ rings (except ipso-C) are omitted for clarity. Selected bond lengths $(\AA)$ and angles $\left({ }^{\circ}\right)$ : $\mathrm{Pt}(1)-\mathrm{P}(1)=2.3116(7), \operatorname{Pt}(1)-\mathrm{P}(2)=$ 2.2568(8), $\mathrm{Pt}(1)-\mathrm{P}(3)=2.3448(7), \mathrm{Pt}(1)-\mathrm{Cl}(1)=2.3591(7), \mathrm{P}(1)-\mathrm{C}(1)=1.883(3)$, $\mathrm{P}(2)-\mathrm{C}(20)=1.904(3), \mathrm{P}(3)-\mathrm{C}(39)=1.893(3), \mathrm{N}(1)-\mathrm{C}(1)=1.352(4), \mathrm{N}(2)-\mathrm{C}(20)=$ $1.362(4), \mathrm{N}(3)-\mathrm{C}(39)=1.352(4), \mathrm{N}(1)-\mathrm{Cl}(2)=3.395(3), \mathrm{N}(2)-\mathrm{Cl}(2)=3.224(3)$, $\mathrm{N}(3)-\mathrm{Cl}(3)=3.227(3) ; \mathrm{P}(1)-\mathrm{Pt}(1)-\mathrm{P}(2)=94.15(3), \mathrm{P}(2)-\mathrm{Pt}(1)-\mathrm{P}(3)=101.27(3)$, $\mathrm{P}(1)-\mathrm{Pt}(1)-\mathrm{Cl}(1)=81.13(3), \mathrm{P}(3)-\mathrm{Pt}(1)-\mathrm{Cl}(1)=83.50(3)$.

We examined two reactions in order to explore the importance of hydrogen bonds between $\mathrm{NH}$ groups and halide ions in our synthetic system. First, the reaction of diiodoplatinum complex $\mathrm{Ptl}_{2}\left(\mathrm{PPh}_{3}\right)_{2}$ with $\mathrm{L}$ was examined, and it was found that the corresponding cage complex was not obtained. The reaction of $\mathrm{PhNHC}(\mathrm{O}) \mathrm{PPh}_{2}$ with $\mathrm{Ptl}_{2}\left(\mathrm{PPh}_{3}\right)_{2}$ also did not give corresponding complex to $\mathbf{3}$. The lower electronegativity of I compared to $\mathrm{Cl}$ or $\mathrm{Br}$ might be responsible for the lack of a hydrogen bond. These results indicate that the hydrogen bond between the phosphinecarboxamide $\left(\mathrm{RNHC}(\mathrm{O}) \mathrm{PR}_{2}^{\prime}\right.$ ) and a halide ion lead to the formation of the cage structure. Next, the reaction of $\mathrm{PtCl}_{2}\left(\mathrm{PPh}_{3}\right)_{2}$ with phosphinethiocarboxamide ligand $\mathrm{Fe}\left(\eta-\mathrm{C}_{5} \mathrm{H}_{4} \mathrm{NHC}(\mathrm{S}) \mathrm{PPh}_{2}\right)_{2} \quad\left(\mathrm{~L}^{\prime}\right)$, which was synthesized according to a previously reported method, ${ }^{6}$ was examined. The NMR spectrum of the reaction mixture showed that a complicated mixture was obtained although an $\mathrm{NH}$ group in thioamide is expected to bind an anion such as $\mathrm{Cl}^{-}$stronger than that in amide. ${ }^{16}$ This result indicates that appropriate acidity of an $\mathrm{NH}$ group is important to keep the cage-shaped molecule.

In summary, we have succeeded in the selective synthesis of unprecedented tetrahedral organic cage complexes involving square-planar Pt complexes. The hydrogen bond between a phosphinecarboxamide and a halide ion plays a significant role in the formation of the cage structure.

This work was supported by a Challenging Exploratory Research Grant (No. 15K13662), a Grant-in-Aid for Science Research Japan (C) (No. 25410073), a Grant-in-Aid for Scientific Research on Innovative Areas "Stimuli-Responsive Chemical Species" (No. 15H00957) from the Ministry of Education, Culture, Sports, Science and Technology, Japan. We thank Dr. R. Tanaka, Osaka City University, for single-crystal X-ray structure analysis. 


\section{Notes and references}

1 Recent reviews of metal-organic cage complexes: (a) R. Chakrabarty, P. S. Mukherjee and P. J. Stang, Chem. Rev., 2011, 111, 6810; (b) H. Amouri, C. Desmarets and J. Moussa, Chem. Rev., 2012, 112, 2015; (c) M. Han, D. M. Engelhard and G. H. Clever, Chem. Soc. Rev., 2014, 43, 1848; (d) Y. Han, J.-R. Li, Y. Xie and G. Guo, Chem. Soc. Rev., 2014, 43, 5952; (e) N. Ahmad, H. A. Younus, A. H. Chughtai and F. Verpoort, Chem. Soc. Rev., 2015, 44, 9; (f) C. J. Brown, F. D. Toste, R. G. Bergman and K. N. Raymond Chem. Rev., 2015, 115, 3012; (g) S. Zarra, D. M. Wood, D. A. Roberts and J. R. Nitschke, Chem. Soc. Rev., 2015, 44, 419; (h) S. H. A. M. Leenders, R. Gramage-Doria, B. de Bruin and J. N. H. Reek, Chem. Soc. Rev., 2015, 44, 433. (i) V. Harsh, Y. Mekhman, V. Francis, Coord. Chem. Rev., 2016, 306, 171.

2 M. Fujita, M. Tominaga, A. Hori and B. Therrien, Acc. Chem. Res., 2005, 38, 371.

3 S. H. Lim and S. M. Cohen, Inorg. Chem., 2013, 52, 7862.

4 (a) M. Fujita, S. Nagao and K. Ogura, J. Am. Chem. Soc., 1995, 117, 1649; (b) M. Hong, Y. Zhao, W. Su, R. Cao, M. Fujita, Z. Zhou and A. S. C. Chan, J. Am. Chem. Soc., 2000, 122, 4819; (c) S. Tashiro, M. Tominaga, T. Kusukawa, M. Kawano, S Sakamoto, K. Yamaguchi and M. Fujita, Angew. Chem. Int. Ed., 2003, 42, 3267; (d) M. Li, P. Cai, C. Duan, F. Lu, J. Xie and Q. Meng, Inorg. Chem., 2004, 43, 5174; (e) S. Ghosh and P. S. Mukherjee, J. Org. Chem., 2006, 71, 8412; (f) A. K. Bar, R. Chakrabarty and P. S. Mukherjee, Inorg. Chem., 2009, 48, 10880; $(g)$ M. D. Ward, Chem. Commun., 2009, 4487 and references therein; $(h)$ A. Stephenson and M. D. Ward Dalton Trans., 2011, 40, 10360; (i) B. R. Hall, L. E. Manck, I. S. Tidmarsh, A. Stephenson, B. F. Taylor, E. J. Blaikie, D. A. V. Griend and M. D. Ward, Dalton Trans., 2011, 40, 12132; (j) A. Stephenson, S. P. Argent, T. Riis-Johannessen, I. S. Tidmarsh and M. D. Ward, J. Am. Chem. Soc., 2011, 133, 858; (k) S. Yi, V. Brega, B. Captain and A. E. Kaifer, Chem. Commun., 2012, 48, 10295; (I) R. Custelcean, P. V. Bonnesen, N. C. Duncan, X. Zhang, L. A. Watson, G. V. Berkel, W. B. Parson and B. P. Hay, J. Am. Chem. Soc., 2012, 134, 8525; $(m)$ M. Ikeda, K. Ohno, Y. Kasumi, S. Kuwahara and Y. Habata, Inorg. Chem., 2014, 53 24; (n) D.-H. Ren, D. Qiu, C.-Y. Pang, Z. Li and Z.-G. Gu, Chem. Commun., 2015, 51, 788; (o) W. Cullen, S. Turega, C. A. Hunter and M. D. Ward, Chem. Sci., 2015, 6, 625.

5 For examples, see: $(a)$ M. Aoyagi, K. Biradha and M. Fujita, J. Am. Chem. Soc., 1999, 121, 7457; (b) K. Umemoto, K. Yamaguchi and M. Fujita, J. Am. Chem. Soc., 2000, 122, 7150 (c) M. D. Ward, J. A. McCleverty and J. C. Jeffery, Coord. Chem. Rev., 2001, 222, 251; (d) Y. Kubota, K. Biradha, M. Fujita, S. Sakamoto and K. Yamaguchi, Bull. Chem. Soc. Jpn., 2002, 75, 559; (e) I. A. Riddell, M. M. J. Smulders, J. K. Clegg Y. R. Hristova, B. Breiner, J. D. Thoburn and J. R. Nitschke, Nat. Chem., 2012, 4, 751; (f) M. C. Young, L. R. Holloway, A. M. Johnson and R. J. Hooley, Angew. Chem. Int. Ed., 2014, 53, 9832.

6 A. C. Behrle and J. A. R. Schmidt, Organometallics, 2013, 32, 1141.

7 (a) B. Cordero, V. Gómez, A. E. Platero-Prats, M. Revés, J. Echeverría, E. Cremades, F. Barragán and S. Alvarez, Dalton Trans., 2008, 2832; (b) P. Pyykkö and M. Atsumi, Chem. Eur. J., 2009, 15, 186.

8 A. R. Jupp and J. M. Goicoechea, J. Am. Chem. Soc., 2013, 135, 19131.

9 M. B. Geeson, A. R. Jupp, J. E. McGrady and J. M. Goicoechea, Chem. Commun., 2014, 50, 12281.

10 There are a few papers on Platinum-based cages. (a) H.-B. Yang, K. Ghosh, A. M. Arif and Peter J. Stang, J. Org. Chem. 2006, 71, 9464; (b) S. Ghosh, S. R. Batten, D. R. Turner and P. S. Mukherjee, Organometallics 2007, 26, 3252; (c) G. H.
Clever, W. Kawamura, S. Tashiro, M. Shiro and M. Shionoya, Angew. Chem. Int. Ed. 2012, 51, 2606; (d) X. Yan, S. Li, J. B. Pollock, T. R. Cook, J. Chena, Y. Zhang, X. Ji, Y. Yu, F. Huang and P. J. Stang, Proc. Natl. Acad. Sci. U.S.A., 2013, 110, 15585; (e) X. Yan, T. R. Cook, P. Wang, F. Huang and P. J. Stang, Nat. Chem. 2015, 7, 342.

11 (a) F. Otón, A. Tárraga, M. D. Velasco, A. Espinosa and P. Molina, Chem. Commun., 2004, 1658; (b) F. Otón, A. Tárraga, A. Espinosa, M. D. Velasco and P. Molina, J. Org. Chem., 2006 71, 4590.

12 There are many anion binding with receptors possessing amide groups reported by other groups. For examples, see: (a) C. R. Bondy and S. J. Loeb, Coord. Chem. Rev., 2003, 240, 77; (b) E. A. Katayev, G. D. Pantos, V. M. Lynch, J. L. Sessler, M. D. Reshetova and Y. A. Ustynyuk, Russ. Chem. Bull., 2005, 165; (c) M. N. Piña, C. Rotger, B. Soberats, P. Ballester, P. M. Deyà and A. Costa, Chem. Commun., 2007, 963; (d) P. A. Gale and C. Caltagirone, Chem. Soc. Rev., 2015, 44, 4212; (e) S. J. Edwards, H. Valkenier, N. Busschaert, P. A. Gale and A. P. Davis, Angew .Chem. Int. Ed. 2015, 54, 4592; (f) N. Busschaert, C. Caltagirone, W. V. Rossom, and P. A. Gale, Chem. Rev. 2015, 115, 8038.

13 (a) F. Zordan, L. Brammer and P. Sherwood, J. Am. Chem. Soc., 2005, 127, 5979; (b) F. Zordan and L. Brammer, Cryst. Growth Des., 2006, 6, 1374; (c) S. M. Walter, M. G. Sarwar, M. G. Chudzinski, E. Herdtweck, A. J. Lough, S. M. Huber and M. S. Taylor, CrystEngComm, 2013, 15, 3097; (d) T. M. Beale, M. G. Chudzinski, M. G. Sarwar and M. S. Taylor, Chem. Soc. Rev. 2013, 42, 1667.

14 Q.-Q. Wang, V. W. Day, K. Bowman-James, J. Am. Chem. Soc., 2013, 135, 392

15 For examples, see: (a) O. M. Yaghi, M. O'Keeffe, N. W. Ockwing, H. K. Chae, M. Eddaoudi and J. Kim, Nature, 2003, 423, 705; (b) S. Kitagawa, R. Kitaura and S. Noro, Angew. Chem. Int. Ed., 2004, 43, 2334; (c) G. Férey, Chem. Soc. Rev., 2008, 37, 191.

16 T. Zieliński, J. Jurczak, Tetrahedron, 2005, 61, 4081. 